\title{
QNREL
}
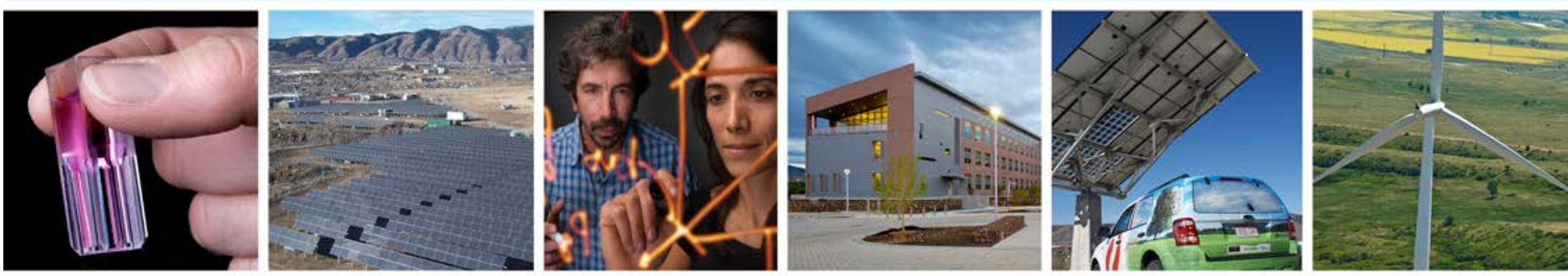

\section{Non-Contact Printed Aluminum Metallization of Si Photovoltaic Devices}

\section{Preprint}

Heather A.S. Platt and Maikel F.A.M. van Hest National Renewable Energy Laboratory

Yunjun Li and James P. Novak Applied Nanotech, Inc.

Presented at the 2012 IEEE Photovoltaic Specialists Conference Austin, Texas June 3-8, 2012 


\section{NOTICE}

The submitted manuscript has been offered by an employee of the Alliance for Sustainable Energy, LLC (Alliance), a contractor of the US Government under Contract No. DE-AC36-08GO28308. Accordingly, the US Government and Alliance retain a nonexclusive royalty-free license to publish or reproduce the published form of this contribution, or allow others to do so, for US Government purposes.

This report was prepared as an account of work sponsored by an agency of the United States government. Neither the United States government nor any agency thereof, nor any of their employees, makes any warranty, express or implied, or assumes any legal liability or responsibility for the accuracy, completeness, or usefulness of any information, apparatus, product, or process disclosed, or represents that its use would not infringe privately owned rights. Reference herein to any specific commercial product, process, or service by trade name, trademark, manufacturer, or otherwise does not necessarily constitute or imply its endorsement, recommendation, or favoring by the United States government or any agency thereof. The views and opinions of authors expressed herein do not necessarily state or reflect those of the United States government or any agency thereof.

Available electronically at http://www.osti.gov/bridge

Available for a processing fee to U.S. Department of Energy and its contractors, in paper, from:

U.S. Department of Energy

Office of Scientific and Technical Information

P.O. Box 62

Oak Ridge, TN 37831-0062

phone: 865.576.8401

fax: 865.576 .5728

email: mailto:reports@adonis.osti.gov

Available for sale to the public, in paper, from:

U.S. Department of Commerce

National Technical Information Service

5285 Port Royal Road

Springfield, VA 22161

phone: 800.553 .6847

fax: 703.605.6900

email: orders@ntis.fedworld.gov

online ordering: http://www.ntis.gov/help/ordermethods.aspx

Cover Photos: (left to right) PIX 16416, PIX 17423, PIX 16560, PIX 17613, PIX 17436, PIX 17721

Printed on paper containing at least $50 \%$ wastepaper, including $10 \%$ post consumer waste. 


\title{
Non-Contact Printed Aluminum Metallization of Si Photovoltaic Devices
}

\author{
Heather A.S. Platt, ${ }^{1}$ Y unjun Li, ${ }^{2}$ James P. Novak, ${ }^{2}$ and Maikel F.A.M. van Hest ${ }^{1}$ \\ ${ }^{1}$ National Renewable Energy Laboratory, Golden, Colorado, United States \\ ${ }^{2}$ Applied Nanotech, Inc., Austin, Texas, United States
}

\begin{abstract}
Alternative solution-based techniques such as aerosol jet printing offer the dual benefits of contactless pattern deposition and high material utilization. We have used aerosol jet printing to investigate non-contact printed Al metal ink as a replacement for screen printed Al back contacts on wafer Si solar cells. This particle-based ink can be prepared at high loadings of 60 weight \% metal, which enables rapid deposition of 1 - $10 \mu \mathrm{m}$ thick lines. Al lines printed on Si wafers and heated between 550 and $800{ }^{\circ} \mathrm{C}$ form low resistance contacts suitable for current extraction. The effectiveness of these printed Al back contacts has further been demonstrated by incorporating them into a series of $21 \mathrm{~cm}^{2}$ crystalline $\mathrm{Si}$ solar cells that produced a champion power conversion efficiency of $13 \%$.
\end{abstract}

Index Terms - printing, aluminum, photovoltaic cells, silicon.

\section{INTRODUCTION}

Rapid deposition of electrically active metal patterns on $\mathrm{Si}$ wafers can be accomplished by a variety of techniques in the large-scale manufacturing environment. Screen printing of metal contacts is the usual method of choice for solar cell production because it is relatively simple and reliable.[1] Cost savings efforts are driving $\mathrm{Si}$ wafers thinner, however, and contact metallization methods like screen printing must be replaced by non-contact methods in order to prevent a concurrent increase in broken wafers. Any non-contact technique that replaces screen printing in large-scale manufacturing must also be capable of depositing films and patterns very quickly ( $>2000$ wafers/hour). Solution-based techniques such as spray pyrolysis and aerosol or ink jet printing satisfy both of these criteria. These large-area ink deposition tools have been incorporated into the Atmospheric Processing Platform (APP) at NREL,[2] along with complementary rapid thermal processing and characterization equipment. The APP provides an inert environment in which substrates up to $156 \mathrm{~mm} \times 156 \mathrm{~mm}$ can be placed to deposit metal films and lines to act as front and back contacts for a wide variety of solar cells.

We have used the aerosol jet printing capability in the APP to investigate non-contact printed $\mathrm{Al}$ metal ink as a possible low-cost replacement for screen printed Al back contacts on wafer Si solar cells. The printed Al features have been heated over a wide temperature range to form low resistance contacts to Si that are suitable for extracting current from solar cells. The effectiveness of these printed Al back contacts has further been demonstrated by incorporating them into a series of 21 $\mathrm{cm}^{2} \mathrm{Si}$ solar cells that produced champion efficiencies of $13 \%$.

\section{METHODS AND RESULTS}

\section{A. Aerosol jet printed Al lines}

Aerosol jet printing is a very versatile technique that can handle inks that have a wide range of viscosities and components.[3] This is particularly advantageous for printing Applied Nanotech's particle-based Al ink, which can be

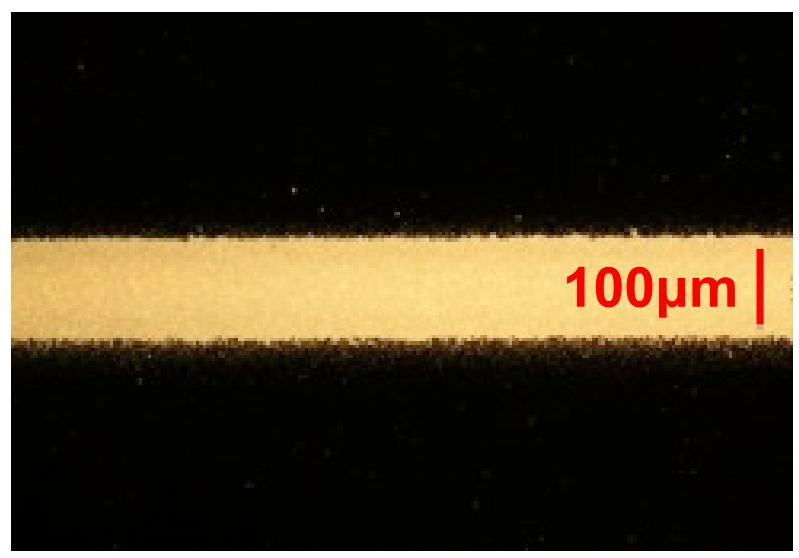

Figure 1. Top down image of an aerosol jet printed Al line.

prepared at high loadings of 60 weight $\%$ metal. This ink has been used to deposit lines with thicknesses in the range of 1 to $120 \mu \mathrm{m}$ thick. As the $10 \mu \mathrm{m}$ thick line in Figure 1 shows, these lines are just over $100 \mu \mathrm{m}$ wide with very little overspray beyond the edges of the lines. The resistivities of such lines printed on glass are $10 \mu \Omega$-cm $(\sim 6 \mathrm{x}$ bulk Al) after appropriate sintering.

\section{B. Al-Si Contact Formation}

Al lines printed on $\mathrm{Si}$ wafers have been heated over a wide temperature range of $550-800{ }^{\circ} \mathrm{C}$ to form low resistance ohmic contacts suitable for current extraction. This range includes temperatures above and below the $\mathrm{Si}-\mathrm{Al}$ eutectic at $577^{\circ} \mathrm{C}$ and the melting point of $\mathrm{Al}$ at $660^{\circ} \mathrm{C}$. Transfer length method patterns consisting of ten parallel lines with line-toline spacings ranging from $700 \mu \mathrm{m}$ to $4800 \mu \mathrm{m}$ were printed on textured $\mathrm{Si}$ wafers and sintered for $4 \mathrm{~min}$ at each temperature to determine contact resistivities. These values 
fell from $80 \mathrm{~m} \Omega-\mathrm{cm}^{2}$ at both 550 and $600{ }^{\circ} \mathrm{C}$ to $20 \mathrm{~m} \Omega-\mathrm{cm}^{2}$ at $800{ }^{\circ} \mathrm{C}$. Profiles of the sintered Al lines in Figure 2 show that

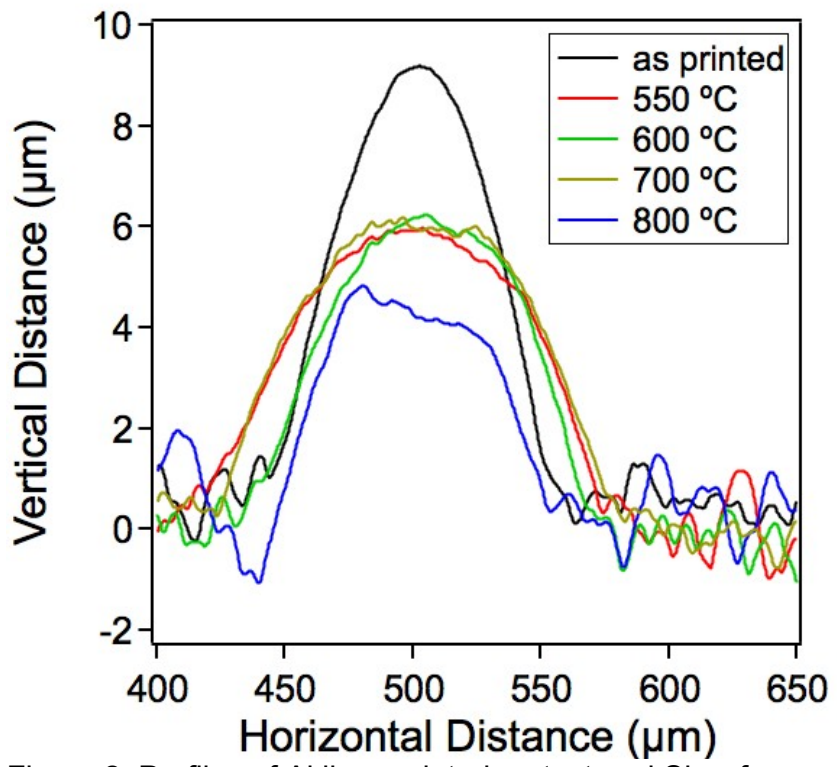

Figure 2. Profiles of Al lines printed on textured Si wafers and fired at the indicated temperatures.

all of the temperatures investigated cause the lines to compress significantly from the original $9 \mu \mathrm{m}$ thick "as printed" line. This behavior is consistent with the $\mathrm{Al}$ melting and $\mathrm{Al}-\mathrm{Si}$ alloying taking place in this temperature range.

\section{Solar Cell Preparation and Performance}

The effectiveness of aerosol jet printed Al back contacts has further been demonstrated by incorporating them into 21 $\mathrm{cm}^{2} \mathrm{Si}$ solar cells with Ag grids as the front contacts. Al lines

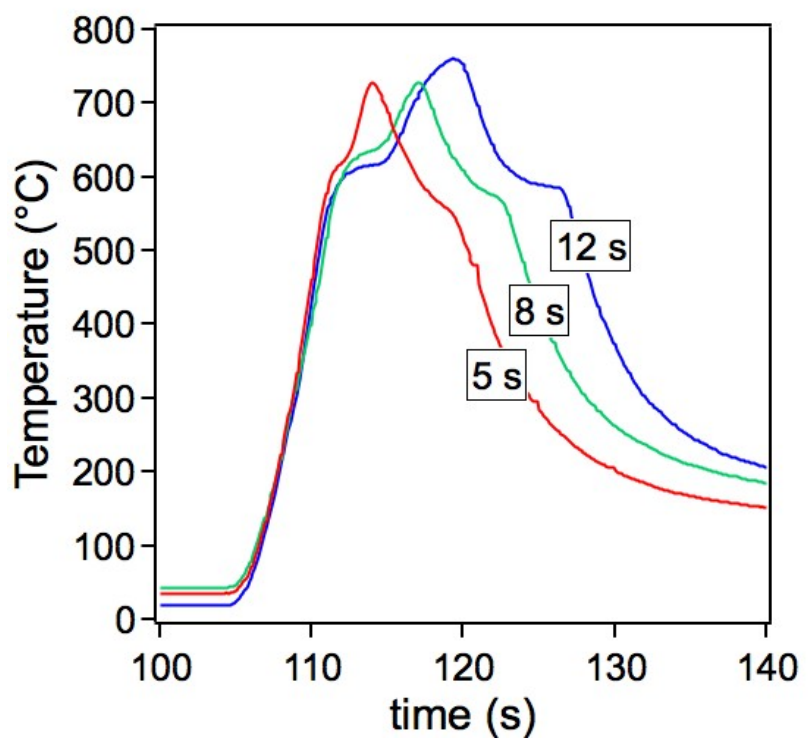

Figure 3. Firing profiles used to form Ag front contacts and Al back contacts to Si solar cells. Labels indicate the length of time above $600{ }^{\circ} \mathrm{C}$. or pads were printed on the back of $\mathrm{Si}$ wafers after commercial Ag paste was screen printed on the $\mathrm{SiN}_{\mathrm{x}}$ antireflective coating (ARC) on the opposite side. The cells were then fired using a rapid thermal processor to diffuse $\mathrm{Al}$ into the back surface of the wafers and burn the Ag paste through the ARC on the front surface.

Co-firing two different metals simultaneously to form useful contacts to both sides of a wafer requires careful consideration of the interaction of both metals with $\mathrm{Si}$. Burning through the ARC also necessitates the inclusion of an oxide-based frit in the Ag paste,[4] which further narrows the processing window. The wide temperature range established for making good electrical contact to $\mathrm{Si}$ with non-contact printed $\mathrm{Al}$ ink allowed us to focus on finding appropriate firing conditions for the $\mathrm{Ag}$ paste. Between 300 and $600{ }^{\circ} \mathrm{C}$ the organic binding agents that boost the Ag paste's viscosity will typically burn off as long as there is sufficient oxygen present. Then a short spike into the $700-800{ }^{\circ} \mathrm{C}$ range drives the frit-SiN ${ }_{\mathrm{x}}$ burn through reaction. Figure 3 shows three of the profiles used to test the effect of the amount of time a wafer spent above $600{ }^{\circ} \mathrm{C}$ on the final cell performance. The peak temperature was also varied.

Figure 4 provides a summary of the efficiencies of cells fired for three different times above $600{ }^{\circ} \mathrm{C}$. There is a clear

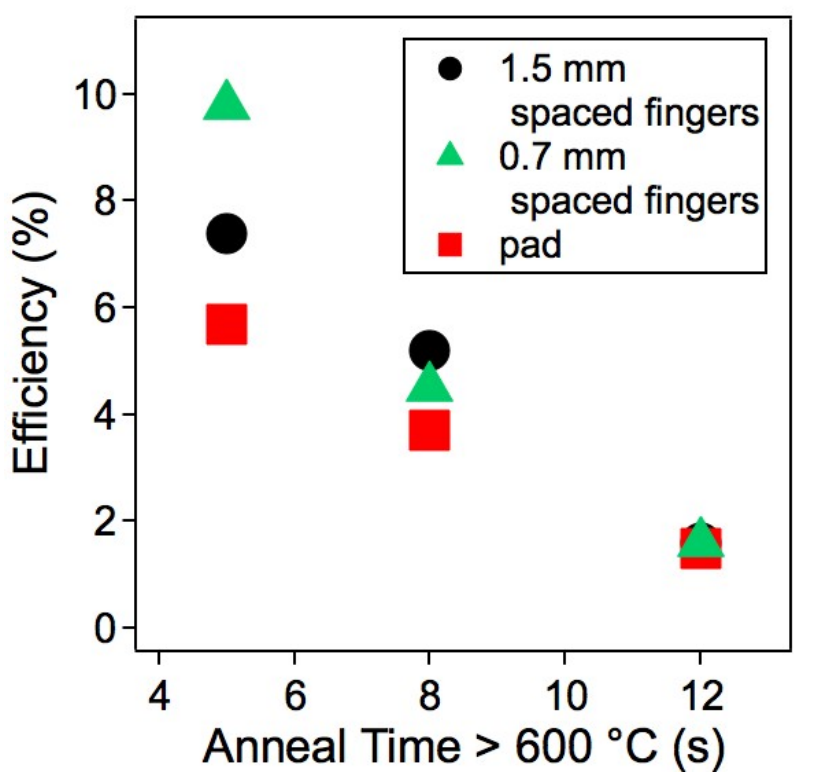

Figure 4. The efficiencies of solar cells heated for different times above $600^{\circ} \mathrm{C}$.

trend toward higher efficiency with shorter firing time, which is driven by a concurrent decrease in the series resistance of the cells. Longer firing times likely cause an increase in series resistance due the reaction of the oxide frit and the oxygen atmosphere with the $\mathrm{Si}$ wafer to form some $\mathrm{SiO}_{\mathrm{x}}$. Peak firing temperature also appears to play a role in device performance, as demonstrated by the higher efficiencies of cells fired at 760 
${ }^{\circ} \mathrm{C}$ than those that only reached $730{ }^{\circ} \mathrm{C}$. In this case, the additional activation energy from the higher temperature may drive the burn through reaction faster.

In addition to the firing optimization studies, we also evaluated the impact of the geometry of the Al back contact on the performance of the solar cells. The aerosol jet printer is designed to print straight lines, so fingers were printed across the back of the wafers with either 1.5 or $0.7 \mathrm{~mm}$ between them. Overlapping lines were also printed on other cells to form continuous pads. The efficiencies of the cells increased as the space between lines decreased, which is the expected trend with increasing Al coverage on the back of the cell. The efficiencies of the pads decreased again, however (see the $5 \mathrm{~s}$ series of cells in Figure 4). This unexpected result may be due to cracking in the pads as the Al contracted during firing, while the additional space around the fingers provided less destructive routes to stress relief during the heating process. Cracks in the pads were easily visible to the eye after firing.

This hypothesis was confirmed by preparing a second series of cells using a different Ag paste and slightly different Al geometries. In addition to full $\mathrm{Al}$ pads and $0.7 \mathrm{~mm}$ spaced fingers, crossed fingers were printed by repeating the $0.7 \mathrm{~mm}$

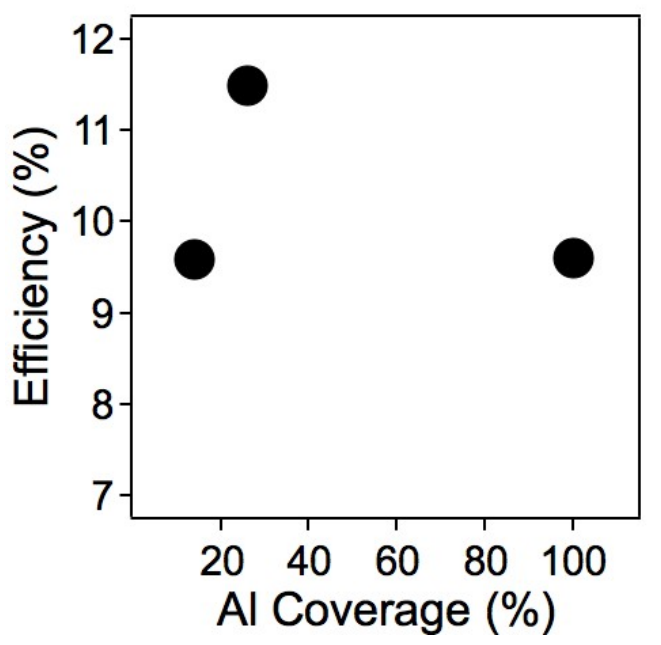

Figure 5. The efficiencies of solar cells prepared with different $\mathrm{Al}$ back contact geometries. finger pattern after rotating the original fingers $90^{\circ}$. These cells were fired by rapid thermal processing as described above. Fig. 5 shows the efficiencies of these cells increasing with increasing Al coverage of the back surface of the cell before dropping again when the entire surface is covered with the pad.

\section{CONCLUSION}

We have demonstrated non-contact printed Al pads and patterns on $\mathrm{Si}$ wafers that can be heated over a wide temperature range to form low resistance contacts suitable for extracting photo-generated current from $\mathrm{Si}$ solar cells. The effectiveness of these printed $\mathrm{Al}$ back contacts has further been demonstrated by incorporating them into $21 \mathrm{~cm}^{2}$ crystalline Si solar cells that produced champion efficiencies of $13 \%$. These promising results demonstrate the potential for non-contact printed $\mathrm{Al}$ to contribute to the fabrication of lowcost photovoltaic devices.

\section{ACKNOWLEDGEMENT}

Applied Nanotech, Inc. would like to thank the US Dept. of Energy for funding this work under contract DE-FG0208ER85085.

\section{REFERENCES}

[1] M Ghannam, S. Sivoththaman, J. Poortmans, J. Szlufcik, J. Nijs, R. Mertens, and R. V. Overstraeten, "Trends in Industrial Silicon Solar Cell Processes," Solar Energy, vol. 59, pp. 101$110,1997$.

[2] National Renewable Energy Laboratory, http://www.nrel.gov/pv/pdil/ap_capabilities.html.

[3] Optomec, http://www.optomec.com.

[4] M. Horteis, T. Gutberlet, A. Reller, and S. W. Glunz, "HighTemperature Contact Formation on n-Type Silicon: Basic Reactions and Contact Model for Seed-Layer Contacts," Advanced Functional Materials, vol. 20, p. 476-484, 2010. 